\title{
RESIDENTIAL DAMP DETECTION WITH TEMPERATURE AND HUMIDITY URBAN SENSING
}

\author{
D. Nepomuceno*, T. Tryfonas and P. J. Vardanega \\ University of Bristol, Bristol, United Kingdom \\ * Corresponding author
}

\begin{abstract}
Residential damp can be detected by measuring the temperature and relative humidity in a given space. With these values, one can infer the dew point, which is an accurate indicator for condensation. By installing sensor networks that can take these relevant measurements, urban sensing systems could be created that help tackle the problem of residential damp. This paper centres in on this concept. Potential urban sensing solutions relevant to damp are surveyed. Three existing initiatives were found as well as a variety of potential solutions, demonstrating the feasibility of such a network to be installed. A sensor - known as the 'Frogbox' - developed from an existing initiative is then deployed in a student residence over a two-week period. From the deployment, it was found that the average humidity was at $56 \%$, which is above the recommended amount. Improvements to the Frogbox could be made by adding a real-time visualisation feature. Given findings from the review and case study, a conceptual urban sensing model for a university student population is then developed.
\end{abstract}

\section{Introduction}

This paper explores the ways in which 'urban sensing' can contribute to the reduction of 'residential damp' in university student accommodations. As sensor technologies become more affordable and mobile, wide sensor networks are increasingly being deployed by citizens, enabling the collective monitoring of an environment through the gathering and sharing of data. This, essentially, is the process of 'urban sensing' - where the capture of previously unattainable real-time information can be used to solve a wide variety of problems.

In a national study for UK university students, $61 \%$ of respondents in the private rented sector reported damp, condensation or mould (NUS, 2014: p. 4). Occupants of damp households have a higher risk of encountering health issues: e.g., 'respiratory symptoms, respiratory infections, allergic rhinitis and asthma' (WHO, 2009). Moreover, university students living in private rented accommodations can be regarded as a vulnerable population due to their low income, tenant status and the UK student housing market perpetuating frequent tenant turnover leading to poor maintenance of accommodation (Lanthier-Veilleux et al., 2016). This paper is based on preliminary work presented in Nepomuceno (2017).

\section{Urban sensing solutions}

In this paper, the term 'urban sensing' (Lane et al., 2008) is used to classify applications where users voluntarily provide sensor data, for both personal and collective advantage. 'Urban sensing' covers terminologies such as 'participatory sensing' (Burke et al., 2006; Lane et al., 2008), 'opportunistic sensing' (Lane et al., 2008), 'citizen sensing' (Balestrini et al., 2017; Burke et al., 2006), 'crowd-sensing' (Dutta et al., 2016), 'community sensing' (Krause et al., 2008) and 'people-centric sensing' (Campbell et al., 2006).

\subsection{Urban sensing initiatives for residential damp}

Three existing urban sensing initiatives were found that have been deployed in the public realm. A common theme among them is that they are 'bottom-up' technologies, where a community of users had come together before the technologies were developed as they had identified a shared problem. This has been fostered by online data sharing platforms (Plenario, 2019; Xively, 2019), the accessibility of open hardware tools (Arduino, 2019) and the low cost of open source sensors (Adafruit, 2019).

Air Quality Egg (AQE) (AQE, 2019) and Smart Citizen (SC) (Diez \& Posada, 2013: p. 3; Smart Citizen, 2019) are both open source urban sensing systems that comprise a sensor node, an online web platform and a mobile application. Both nodes can detect temperature and humidity. Data from the nodes are sent to an online platform in real-time, where they are displayed on a public website.

The Dampbusters initiative (Balestrini et al., 2017) was the only implementation of urban sensing that directly sought to tackle damp. It was borne out of the 'City-Commons Framework for Citizen Sensing' (Balestrini et al., 2017). In Bristol, where Dampbusters was created, this framework was known as 'The Bristol Approach to Citizen Sensing' (KWMC, 2016). The key aim of the framework is to ensure open sensor technologies are 'co-designed by citizens' to address concerns in the community (KWMC, 2016). The development, implementation and outcomes of Dampbusters can be found in Balestrini et al. (2017). 
Table 1 Summary of urban sensing solutions

\begin{tabular}{|c|c|c|c|c|c|}
\hline $\begin{array}{l}\text { (Potential) } \\
\text { solution } \\
\text { Deployed } \\
\text { Systems }\end{array}$ & Description & $\begin{array}{l}\text { Sensor node } \\
\text { capabilities }\end{array}$ & $\begin{array}{l}\text { Platform } \\
\text { capabilities }\end{array}$ & Application to damp & Reference \\
\hline Air Quality Egg & $\begin{array}{l}\text { 'Community-led } \\
\text { sensing network for } \\
\text { AQ monitoring' }\end{array}$ & $\begin{array}{l}\text { Temp., RH, carbon } \\
\text { monoxide (CO), } \\
\text { nitrogen dioxide } \\
\text { (NO2) }\end{array}$ & $\begin{array}{c}\text { Map-based visual.; } \\
\text { web/mobile application }\end{array}$ & $\begin{array}{c}\text { Measure 'damp' } \\
\text { through temp. and RH } \\
\text { readings }\end{array}$ & $\begin{array}{l}\text { AQE } \\
(2019)\end{array}$ \\
\hline Smart Citizen & $\begin{array}{l}\text { 'Open source } \\
\text { participatory sensing } \\
\text { platform' }\end{array}$ & $\begin{array}{l}\text { Temp., RH, CO, } \\
\text { NO2, solar } \\
\text { radiation, sound }\end{array}$ & $\begin{array}{c}\text { Map-based visual.; } \\
\text { web/mobile application; } \\
\text { share data on social } \\
\text { media }\end{array}$ & $\begin{array}{l}\text { Measure 'damp' } \\
\text { through temp. and RH } \\
\text { readings }\end{array}$ & $\begin{array}{l}\text { Smart } \\
\text { Citizen } \\
(2019)\end{array}$ \\
\hline Dampbusters & $\begin{array}{l}\text { 'Citizen-sensing } \\
\text { network to reduce } \\
\text { household damp' }\end{array}$ & $\begin{array}{c}\text { Temperature and } \\
\text { RH }\end{array}$ & N/A & $\begin{array}{l}\text { Could be optimised and } \\
\text { scaled for university } \\
\text { wide area }\end{array}$ & $\begin{array}{l}\text { KWMC } \\
(2016)\end{array}$ \\
\hline \multicolumn{6}{|c|}{ Emerging technologies } \\
\hline EnviObserver & $\begin{array}{l}\text { Enables users 'to } \\
\text { report environmental } \\
\text { observations with a } \\
\text { mobile phone' }\end{array}$ & $\begin{array}{l}\text { None - qualitative } \\
\text { descriptions given } \\
\text { by users \& Map- } \\
\text { based visualisation }\end{array}$ & $\begin{array}{c}\text { Map-based } \\
\text { visualisation; interface } \\
\text { to input/access data }\end{array}$ & $\begin{array}{l}\text { Users would be able to } \\
\text { report damp conditions } \\
\text { in their household }\end{array}$ & $\begin{array}{l}\text { Kotovirta } \\
\text { et al. } \\
(2012)\end{array}$ \\
\hline $\begin{array}{l}\text { Social Sensing } \\
\text { Air Quality } \\
\text { Concept }\end{array}$ & $\begin{array}{c}\text { Air quality can be } \\
\text { recorded in real-time } \\
\text { whilst moving around } \\
\text { a city }\end{array}$ & $\begin{array}{c}\text { Temperature, RH, } \\
\text { other pollutant } \\
\text { values; maker- } \\
\text { friendly \& Map- } \\
\text { based visual.; share } \\
\text { data on social media }\end{array}$ & $\begin{array}{l}\text { Map-based visual.; } \\
\text { share data on social } \\
\text { media }\end{array}$ & $\begin{array}{l}\text { Sensor small enough } \\
(10 \times 10 \times 10 \mathrm{~cm}) \text { to be } \\
\text { used indoors }\end{array}$ & $\begin{array}{l}\text { Capezzuto } \\
\text { et al. } \\
(2014)\end{array}$ \\
\hline $\begin{array}{l}\text { Unified Sensing } \\
\text { Platform }\end{array}$ & $\begin{array}{l}\text { 'Enables participatory } \\
\text { sensing for environ. } \\
\text { monitoring' }\end{array}$ & $\begin{array}{l}\text { Temperature, } \mathrm{RH} ; \\
\text { mobile }\end{array}$ & $\begin{array}{l}\text { Map-based visual.; } \\
\text { support for `operator- } \\
\text { initiated measurement } \\
\text { campaigns'; alerts for } \\
\text { threshold exceedance }\end{array}$ & $\begin{array}{l}\text { 'Alerts' feature could } \\
\text { lend to automatic } \\
\text { actuation given the } \\
\text { exceedance of a } \\
\text { threshold }\end{array}$ & $\begin{array}{l}\text { Zeiger \& } \\
\text { Huber } \\
(2014)\end{array}$ \\
\hline $\begin{array}{l}\text { Air Quality } \\
\text { Monitoring } \\
\text { Device }\end{array}$ & $\begin{array}{l}\text { System that can } \\
\text { generate indoor and } \\
\text { outdoor 'pollution } \\
\text { heat maps' }\end{array}$ & $\begin{array}{c}\text { Temperature, } \mathrm{RH}, \\
\text { other pollutant } \\
\text { values }\end{array}$ & $\begin{array}{l}\text { Map-based visual.; can } \\
\text { gather and share data to } \\
\text { the cloud }\end{array}$ & $\begin{array}{l}\text { Could map 'damp' } \\
\text { within households and } \\
\text { across city locations }\end{array}$ & $\begin{array}{l}\text { Dutta et } \\
\text { al. }(2016)\end{array}$ \\
\hline $\begin{array}{l}\text { Crowd-Sensing } \\
\text { Component }\end{array}$ & $\begin{array}{l}\text { Wearable temp. and } \\
\text { RH sensor node }\end{array}$ & $\begin{array}{l}\text { Gas, temp., RH and } \\
\text { atmospheric } \\
\text { pressure; Bluetooth }\end{array}$ & N/A & $\begin{array}{c}\text { Enhancement of } \\
\text { temporal and spatial } \\
\text { density of data' }\end{array}$ & $\begin{array}{l}\text { Oletic \& } \\
\text { Bilas } \\
(2015)\end{array}$ \\
\hline $\begin{array}{l}\text { Automated Data } \\
\text { Acquisition } \\
\text { System }\end{array}$ & $\begin{array}{l}\text { Low cost digital infra. } \\
\text { for temp. and RH } \\
\text { monitoring based on } \\
\text { the IoT }\end{array}$ & $\mathrm{N} / \mathrm{A}$ & $\begin{array}{l}\text { Defines DAS } \\
\text { architecture for temp. } \\
\text { and RH sensors to } \\
\text { enable IoT connectivity }\end{array}$ & $\begin{array}{l}\text { Enable bespoke system } \\
\text { for damp, due to its } \\
\text { focus on temperature } \\
\text { and RH }\end{array}$ & $\begin{array}{c}\text { Simões \& } \\
\text { de Souza } \\
(2016)\end{array}$ \\
\hline
\end{tabular}

\subsection{Potential urban sensing solutions for damp}

Six 'potential' solutions were found in the literature. These are summarised in Table 1. The capabilities in Capezzuto et al. (2014), Zeiger \& Huber (2014) and Dutta et al. (2016) all include a web-based platform that enables the sharing of data from sensors capable of measuring temperature and relative humidity (RH). Whilst these studies did not focus on 'damp', the tools developed could be used to tackle the issue.

Oletic \& Bilas (2014) present the design of a 'battery-powered, wearable sensor node' that has been optimised for crowdsensing applications. Simões \& de Souza (2016) outline a lowcost digital infrastructure for temperature and $R H$ monitoring based on the IoT. The Data Acquisition System (DAS) Simões \& de Souza (2016) introduce can be used to form an urban sensing system tailored for damp, particularly due to its focus on temperature and $R H$.

\section{Frogbox case study}

This case study utilises the sensor - known as the Frogbox developed in the Dampbusters initiative (Balestrini et al., 2017). This 'sensor deployment study' (Webb et al., 2015) was conducted to test the Frogbox sensors in a practical setting. A schematic for the sensor shown in Figure 1. The Frogbox was used to take temperature and $R H$ readings over a two-week period in a private rented student household. Comprehensive details of this case study can be found in Nepomuceno (2017).

Figure 1 Schematic of Frogbox's functional architecture

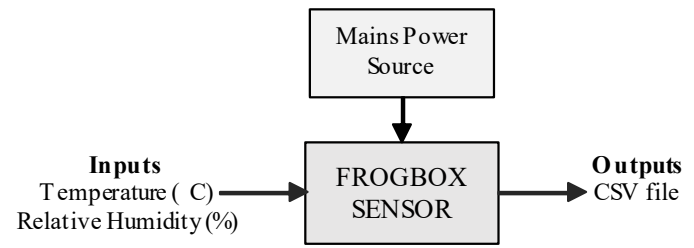




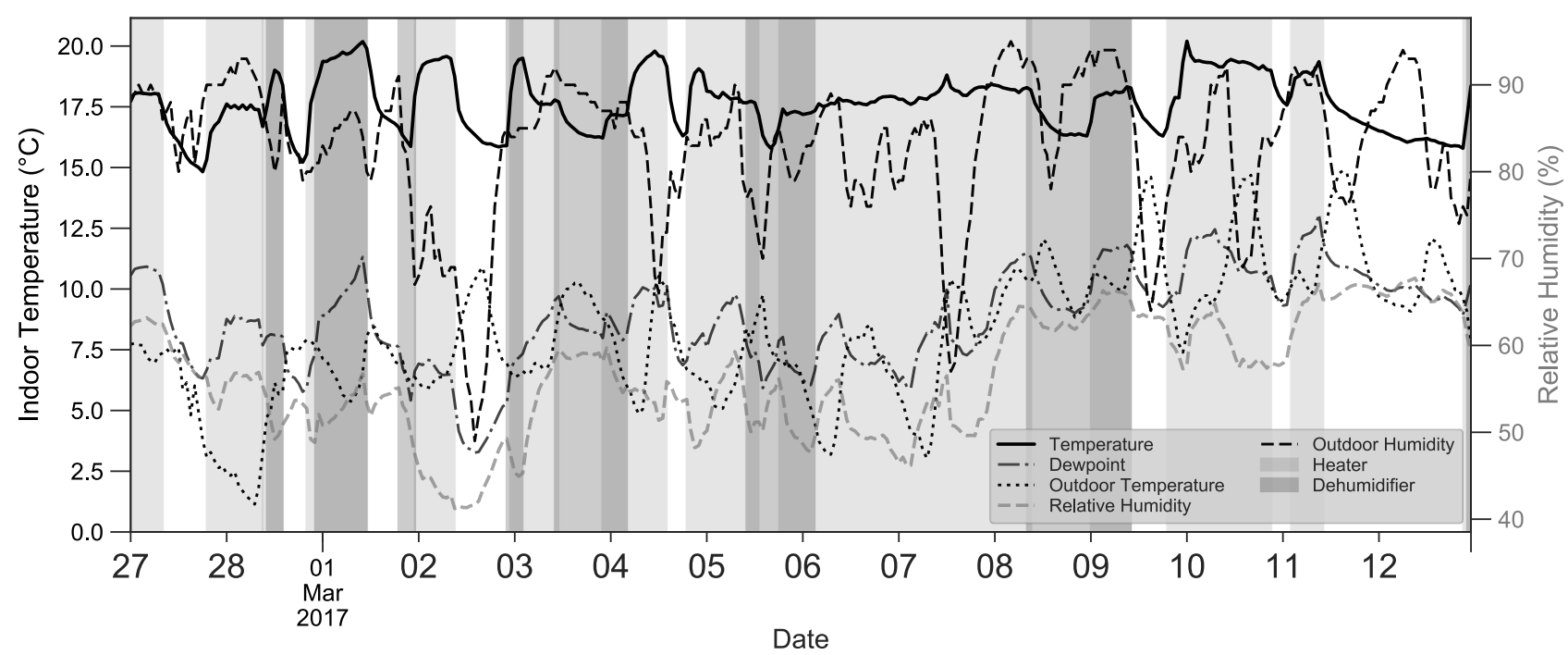

\subsection{Monitoring set-up}

The Frogbox comprises of a Raspberry Pi 3 computer and DHT22 temperature-humidity sensor encased in bespoke green plastic casing. The DHT22 sensor utilises a 'capacitive humidity sensor and thermistor' to measure surrounding air, outputting a digital signal (Adafruit, 2019). The Frogbox works for a temperature range of $-40^{\circ} \mathrm{C}$ to $80^{\circ} \mathrm{C}$, with $\pm 0.5^{\circ} \mathrm{C}$ accuracy, and for a 0 to $100 \%$ RH range with $2-5 \%$ accuracy (Adafruit, 2019). The Frogbox was programmed by KWMC technicians to take readings every five minutes immediately after being connected to a mains power source (i.e. at zero, five, ten, 15 etc. minutes past the hour).

The case study residence is an 8-bed, five-storey terraced house occupied at the time of the study by University of Bristol students in Clifton, Bristol. There are two bedrooms in the basement, and on each of the $1^{\text {st }}, 2^{\text {nd }}$ and $3^{\text {rd }}$ floors. The building is of masonry construction and has a gas central heating system for all floors, barre the basement. The Frogbox was placed in a basement bedroom $\left(10 \mathrm{~m}^{2}\right.$ floor area) with one single-glazed double-hung window (approx. $1.575 \mathrm{~m}^{2}$ ). A wall mounted electric heater was the room's primary heat source and a 'hit and miss' vent below the window $(300 \times 150 \mathrm{~mm})$ allowing for some ventilation. This room was chosen due to the presence of damp patches on the ceiling, and was thought to be susceptible to condensation. The room received low levels of sunlight, reducing natural heat. A dehumidifier was regularly used. Readings were taken over a two-week period, from 2017-0228 00:00 to 2017-03-12 23:55. The first author recorded when the electric heater and dehumidifier were in operation.

\subsection{Data processing}

The Frogbox successfully took temperature and RH readings every five minutes over the monitoring period. Data readings were stored on a MySQL workbench on the Raspberry Pi 3. Data was exported as a .CSV file, consisting of a time stamp, a Frogbox ID, temperature reading $\left({ }^{\circ} \mathrm{C}\right)$ and a $R H$ reading $(\%)$. 4018 readings were taken over the two weeks. This is less than the expected number of 4032 (two weeks $=20160$ mins; 20160/5mins $=4032$ ). This loss of 14 readings may have occurred due to transmission errors or power glitches, but this was deemed negligible in proportion to the results obtained.

The dew point of a body of air can be used as an indicator for condensation, of which high levels can lead to damp conditions (USEPA, 2013: p. 15). Therefore, the corresponding dew point for each reading was calculated using the following equation (Hornbuckle, 2006):

$D=\frac{c \gamma}{b-\gamma}$

where,

$\gamma=\log \frac{R H}{100}+\frac{b T}{c+T}$

where, $D=$ dew point $\left({ }^{\circ} \mathrm{C}\right), R H=$ relative humidity $(\%), T=$ temperature $\left({ }^{\circ} \mathrm{C}\right.$ ), $b=17.27$ (water vapour), $c=237.7$ (barometric pressure) (Hornbuckle, 2006).

Hourly outdoor temperature and RH data for the same time period was taken from the online weather service 'Dark Sky' (Dark Sky, 2018).

\subsection{Results and analysis}

The full set of the measured data including the dew point, as well as time series for individual days is available on the University of Bristol's Research Data Repository (Nepomuceno, 2019). The time series plotted for the full twoweek period is shown in Figure 2. The shaded regions on the plot denote when the electric heater and dehumidifier were in operation.

During the time period where data was collected, the $R H$ ranged from $40.3 \%$ to $68.7 \%$, averaging at $56.5 \%$ (standard deviation $(S D)=6.7 \%$ ). The ideal $R H$ in a home is usually quoted around $50-55 \%$ (USEPA, 2013). 
The dew point ranges from $3.0^{\circ} \mathrm{C}$ to $13.3^{\circ} \mathrm{C}$ over the two-week period with a mean value of $8.8^{\circ} \mathrm{C}\left(S D=1.9^{\circ} \mathrm{C}\right)$. As the dew point gets closer to the indoor air temperature, the relative humidity of the air increases. This effect can be seen in Figure 3 below, where 'Temperature Difference' is defined as the difference between the indoor air temperature and the dew point.

Figure 3 Plot showing variation over time of the relative humidity and the difference between the dew point and indoor air temperature.

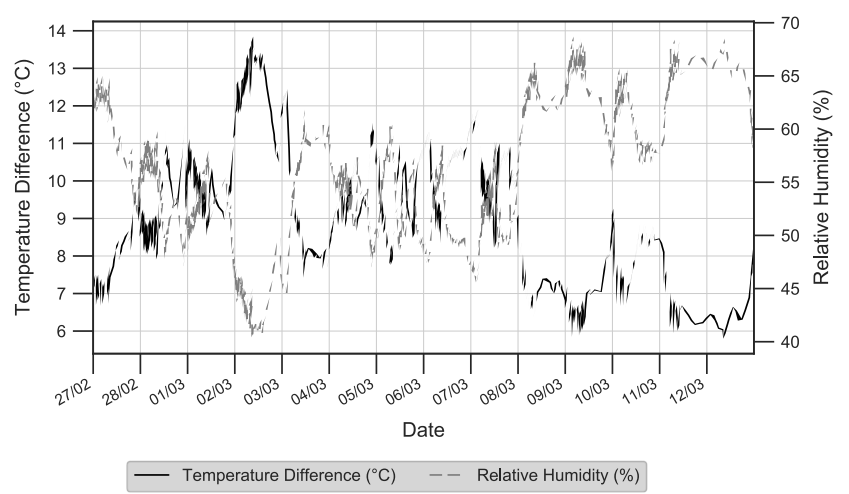

The dew point never exceeded the indoor temperature the two weeks, however it surpassed the outdoor temperature at least once every day. Long periods were observed when it was higher than the outdoor temperature $(17 / 02,28 / 02,01 / 03$, 03/03 04/03, 06/03).

The operation of the electric heater clearly affects the indoor temperature. Generally, it has a stabilising effect, usually raising the temperature to a consistent level. This can be seen in all the shaded regions on the daily graphs. By plotting the indoor air temperature against the relative humidity during periods of heater operation, hardly any correlation is seen (see Figure 4).

The effect of the dehumidifier on the indoor temperature and RH seems inconclusive. At times when it was operating on its own, there are occasions when the RH drops (01/03), RH stays the same $(03 / 03,10 / 02)$, RH increases $(05 / 03)$ and $\mathrm{RH}$ fluctuates (08/03). This lack of correlation may be due to the dehumidifier reaching its full water capacity as aforementioned, or the introduction of moisture sources to the room.

\subsection{Value to occupant}

To improve the Frogbox, the case made apparent the need for a real-time visualisation function, so effects of actions inside the room could be seen. A capability for automatic actuations could be added; such that appliances can be triggered for operation, over a certain RH level. This maintenance would greatly improve the local environment within the room. These improvements are considered in the development of the concept model below.
Figure 4 Plot showing indoor temperature against indoor relative humidity for periods when heater was in operation (NB $r=$ correlation coefficient).

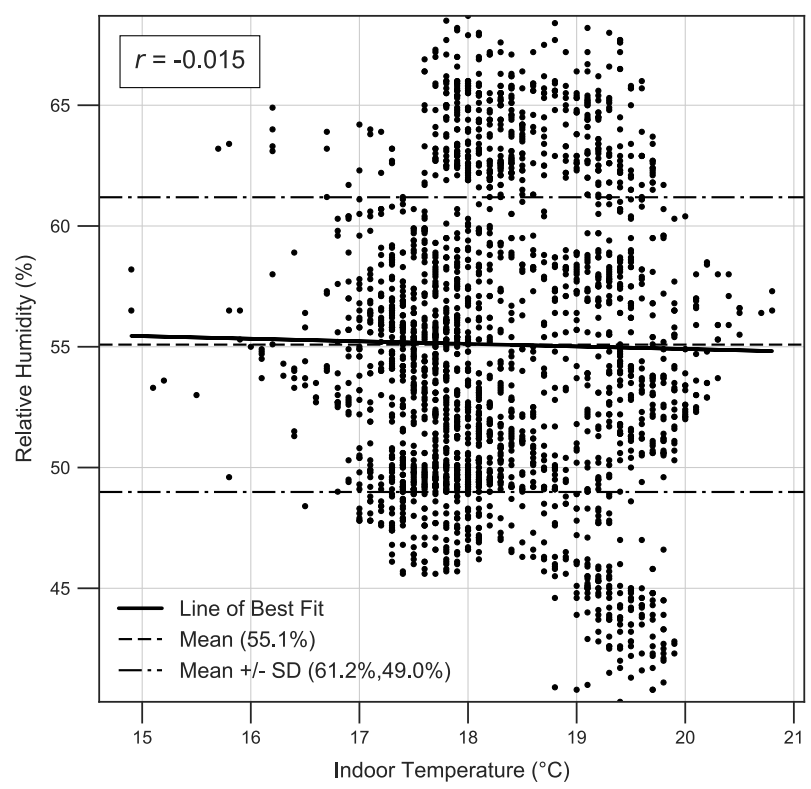

\section{Future system architecture and feasibility}

From the user's perspective (i.e. the student/occupant), the system seen in Figure 5 would operate as follows. A damp sensor capable of recording temperature and $\mathrm{RH}$ is placed in a student household. Through a bespoke smartphone application, the user can: (1) view this local data in a similar visual style to the time-series in Figure 2, (2) view the data of other households connected to the app and (3) upload summaries of their data to social media. The user will also have the option to input relevant socio-geographic characteristics such as those used by Lanthier-Veilleux et al. (2016: p. 5). From this, vulnerable students could be identified, and recommended $\mathrm{RH}$ and/or dew point thresholds can be specified. If this threshold is exceeded, then certain actions can be executed. Firstly, the sensor can trigger an actuator (e.g. heater, dehumidifier) which can lower the RH to a suitable level, thus reducing the risk of damp. Secondly, if there is significant exceedance, then relevant stakeholders can be notified. These stakeholders could include relevant university services, the local council authorities, letting agencies/landlords and housing associations (ACORN, 2019). This awareness would prompt stakeholders to take appropriate action, whether that be carrying out repairs/maintenance on the household or offering support to the affected user.

Central to this network will be a backend database and a web server. The backend is where data received from the sensors will be stored, aggregated, processed and analysed. Specifically, this is where dew point will be calculated, where users can access the app and where data to stakeholders is sent from. Alternatively, this could be done through cloud computing as in Dutta et al., 2016). Device communication within the network will be enabled through Bluetooth (for within household) and Internet (Wi-Fi or cellular data) connections. The map (in Figure 5) represents how the system 
could collectively monitor residential levels in an area and 'connect' households affected by damp; enhancing the region's digital infrastructure and encouraging community engagement.

Figure 5 System architecture for future case in a university accommodation setting (Map data from Google 2019)

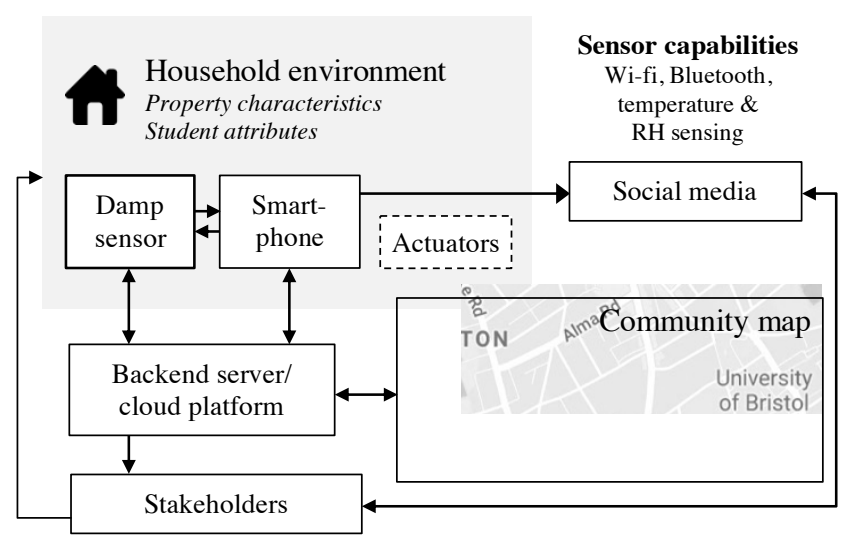

\subsection{Potential Deployment Scenarios}

Based on the data gathered from the case study (Section 3), we can estimate the expected data output and power consumption for an individual sensor over a one-year period. The .CSV file containing the output data for the two weeks was $197 \mathrm{~KB}$ in size. A .CSV file was created to emulate a year's worth of data, and this took up 5.1MB of memory. Each daily plot (.SVG) produced was $80 \mathrm{~KB}$, so the yearly plot data output can be estimated as $29.2 \mathrm{MB}$. The average power consumption of the Frogbox sensor is $4 \mathrm{~W} / \mathrm{h}(0.004 \mathrm{kWh})$. If continuously operating for one year, it would consume $140.2 \mathrm{kWh}$. Multiplying this by the average $\mathrm{kWh}$ unit price in the UK (12.5p (UK Power, 2019)) we can estimate the electricity cost of running one sensor over the course of one year. These annual estimations for one sensor are summarised in Table 2 below.

Table 2 Estimated annual data output and power consumption for one sensor

\begin{tabular}{llll}
\hline Output data & Plot data & $\begin{array}{l}\text { Power } \\
\text { consumption }\end{array}$ & $\begin{array}{l}\text { Cost } \\
\text { electricity }\end{array}$ \\
\hline $5.1 \mathrm{MB}$ & $29.2 \mathrm{MB}$ & $140.2 \mathrm{kWh}$ & $£ 17.52$ \\
\hline
\end{tabular}

Using these figures, we can estimate the anticipated data traffic for two potential deployment scenarios: (a) an installation into 50 student homes, and (b) installation into Bristol University residential halls. For the hypothetical deployment of one sensor in 50 homes, the anticipated traffic can be found in Table 3.

Table 3 Estimated annual data output and power consumption for deployment in 50 homes

\begin{tabular}{lllll}
\hline Output data & Plot data & $\begin{array}{l}\text { Power } \\
\text { consumption }\end{array}$ & $\begin{array}{l}\text { Cost } \\
\text { electricity }\end{array}$ \\
\hline $255 \mathrm{MB}$ & $1.46 \mathrm{~GB}$ & $7010 \mathrm{kWh}$ & $£ 876$ \\
\hline
\end{tabular}

The second scenario anticipates that one sensor being installed for each person living in undergraduate halls at the University of Bristol. There are 24 residential halls, with a total of 5760 places (University of Bristol, 2019), which is assumed to roughly equal the number of rooms.

Table 4 Estimated annual data output and power consumption for a deployment for each room in Bristol University residential halls

\begin{tabular}{llll}
\hline $\begin{array}{l}\text { Output } \\
\text { data }\end{array}$ & Plot data & $\begin{array}{l}\text { Power } \\
\text { consumption }\end{array}$ & $\begin{array}{l}\text { Cost of } \\
\text { electricity }\end{array}$ \\
\hline $29.38 \mathrm{~GB}$ & $168.19 \mathrm{~GB}$ & $807 \mathrm{E} 10^{3} \mathrm{kWh}$ & $£ 100,915$ \\
\hline
\end{tabular}

\subsection{Challenges and considerations}

An argument can be made against a high adoption rate of the urban sensing system outlined above. Student housing contracts typically last 12 months. This frequent turnover of tenants could lead to maintenance being neglected. This raises an interesting question - do the majority of student tenants deeply concerned about their rented household if they are only there for a year? If yes, then adoption rates may be low. Many students visit home during term breaks meaning a rented residence could be vacant for a significant proportion of its tenancy. This raises another interesting issue - should the onus be put on letting agencies for providing extra maintenance to student properties knowing that many of their student properties are vacant for much of the year? Data from the urban sensing system could perhaps be used to infer occupancy, helping investigate this.

Discussions with employees from ACORN on the potential for the 'Dampbusters' initiative to tackle damp, revealed there is relatively low market interest from housing organisations, as it was not viewed as a short-term concrete solution. Generally, tenants affected by damp want instantaneous action from their landlord. Again, this may translate to a low uptake of an urban sensing system as described in this paper. However, market intelligence points at its usefulness as part of a wider campaign against damp, where data can be used to highlight vulnerable households. In practice, various kinds of stakeholders should be considered in 'all steps of the deployment process' (Resch et al., 2011). There are parallels to this notion in the 'Framing' stage of the citizen sensing framework presented by (Balestrini et al., 2017).

Other thematic challenges include privacy, quality of data and ownership of data. Users' privacy concerns must be identified and addressed. Shilton et al. (2008) have developed design principles to address this genuine dilemma in the field. This issue may find new importance due to the Investigatory Powers Act (2016) which allows governmental authorities access to Internet communications data without warrant (IPA, 2016). To ensure a high uniform standard of data, readings must be collected consistently (e.g. sensor staying in the same place). The significantly varying lifestyles of students mean this may be difficult. Data ownership is also a notable concern. The question of who owns the data - the tenants or the property landlord - was found to be a source of 'tension' in the implementation of the 'Dampbusters' initiative (Balestrini et al., 2017). This would be of particular concern to landlords, if readings made public indicated a poor standard of property. 


\section{Summary}

This paper has contributed to a growing body of knowledge on tackling residential damp using urban sensing systems. The research applies this technology to the context of university student accommodation, arguing that students should be regarded as a 'vulnerable population at risk of living in damp households' (Lanthier-Veilleux et al., 2016). Urban sensing solutions were surveyed which demonstrate the feasibility of such a sensor network to be implemented. A case study on a student residence using KWMC's Frogbox was conducted to assess its value to the occupant. This led to the development of a concept urban sensing model for university student populations which improves the built environment by maintaining humidity levels in a household. The relative merits and short-comings of this model are discussed, outlining implications for relevant stakeholders.

\section{Acknowledgements}

The authors would like to thank Martha King (Arts Producer, KWMC), Hayden West (Creative Technology Technician, KWMC), Stephen Le Fanu (Former Student Living Officer, UoB) and Nick Ballard (Community Organiser, ACORN) for their kind contributions. The authors would also like to acknowledge UKCRIC Urban Observatories (grant number $\mathrm{EP} / \mathrm{P} 016782 / 1)$, as well as additional support from the Engineering and Physical Sciences Research Council (EPSRC) through the National Productivity Investment Fund (grant number EP/R51245X/1).

\section{Data availability statement}

The underlying research data presented in this paper can be downloaded from the University of Bristol's Research Data Repository (Nepomuceno, 2019).

\section{References}

ACORN (Association of Community Organisations for Reform Now). (2019). ACORN homepage. https://acorntheunion.org.uk/ (accessed 02/04/2019).

Adafruit. (2019). DHT22 temperature-humidity sensor + extras. https://www.adafruit.com/product/385 (accessed 02/04/2019).

AQE (Air Quality Egg). (2019). Air Quality Egg homepage. http://airqualityegg.com/ (accessed 02/04/2019).

Arduino. (2019). What is Arduino? https://www.arduino.cc/en/Guide/Introduction (accessed 02/04/2019).

Balestrini, M. Rogers, Y. Hassan, C. Creus, J. King, M. \& Marshall, P. (2017). A City in Common: A Framework to Orchestrate Large-scale Citizen Engagement around Urban Issues. Ideas for Change. Available at: https://www.ideasforchange.com/s/CHI-

2017_cameraready_final.pdf (accessed 02/04/2019).

Burke, J. Estrin, D. Hansen, M. Parker, A. Ramanathan, N. Reddy, S. \& Srivastava, MB. (2006). Participatory Sensing. Workshop on World-Sensor-Web: Mobile Device Centric
Sensor Networks and Applications. Available at: http://citeseer.ist.psu.edu/viewdoc/download?doi=10.1.1.122. $3024 \&$ rep $=$ rep1\&type $=$ pdf $($ accessed 02/04/2019).

Campbell, A.T. Eisenman, S.B. Lane, N.D. Miluzzo, E. \& Peterson, R.A. (2006). People-centric urban sensing. Proceedings of the Second Annual International Workshop on Wireless Internet (WICON '06). ACM, New York, NY, USA, Article 18. https://doi.org/10.1145/1234161.1234179

Capezzuto, L. Abbamonte, L. De Vito, S. Massera, E. Formisano, F. Fattoruso, G. Di Francia, G. \& Buonanno A. (2014). A maker friendly mobile and social sensing approach to urban air quality monitoring. IEEE SENSORS 2014 Proceedings. Valencia, 2014, pp. 12-16. https://doi.org/10.1109/ICSENS.2014.6984920

Dark Sky. (2019). Weather in Bristol, England, United Kingdom. https://darksky.net/forecast/51.4558,2.6122/si12/en (accessed 02/04/2019).

Diez, T. \& Posada, A. (2013). The fab and the smart city: the use of machines and technology for the city production by its citizens. Proceedings of the Seventh International Conference of Tangible, Embedded and Embodied Interaction, Barcelona 2013 pp. 447-454. https://doi.org/10.1145/2460625.2460725

Dutta, J. Gazi, F. Roy, S. \& Chowdhury, C. (2016). AirSense: Opportunistic crowd-sensing based air quality monitoring system for smart city. 2016 IEEE SENSORS, Orlando, FL, 2016, pp. 1-3. https://doi.org/10.1109/ICSENS.2016.7808730

Hornbuckle, B. (2006). Function $[\mathrm{Td}]=\mathrm{dp}(\mathrm{Ta}, \mathrm{rh})$. Dr. Brian Hornbuckle. http://bkh.public.iastate.edu/teaching/505/dp.m (accessed 02/04/2019).

IPA (Investigatory Powers Act). (2016). 2016 Chapter 25. http://www.legislation.gov.uk/ukpga/2016/25/contents/enacte d/data.htm (accessed 02/04/2019).

Kotovirta, V. Toivanen, T. Tergujeff, R. \& Huttunen, M. (2012). Participatory Sensing in Environmental Monitoring Experiences. Sixth International Conference on Innovative Mobile and Internet Services in Ubiquitous Computing. Palermo, 2012, pp. 155-162. https://doi.org/10.1109/IMIS.2012.70

Krause, A. Horvitz, E. Kansal, A. \& Zhao, F. (2008). Toward Community Sensing. 2008 International Conference on Information Processing in Sensor Networks. St. Louis, MO, pp. 481-492. https://doi.org/10.1109/IPSN.2008.37

KWMC (Knowle West Media Centre). (2016). The Bristol Approach in action. [e-book] Knowle West Media Centre. https://issuu.com/knowlewestmedia/docs/bristol_approach_bo oklet_issu (accessed 02/04/2019).

Lane, N.D. Eisenman, S.B. Musolesi, M. Miluzzo, E. \& Campbell, A.T. (2008). Urban sensing systems: opportunistic or participatory? Proceedings of the Ninth workshop on Mobile computing systems and applications (HotMobile '08). ACM, New York, NY, USA, 11-16. http://dx.doi.org/10.1145/1411759.1411763

Lanthier-Veilleux, M. Généreux, M. \& Baron, G. (2016). Prevalence of Residential Dampness and Mold Exposure in a University Student Population. International Journal of Environmental Research and Public Health 13(2): 194. http://doi.org/10.3390/ijerph13020194 
Nepomuceno, D. (2017). Toward the reduction of reduction of residential damp in university student populations: an exploration of urban sensing. Undergraduate Research Report 1617RP0009m, University of Bristol, Bristol, UK.

Nepomuceno, D. (2019). Supporting data for "Residential Damp Detection with Temperature and Humidity Urban Sensing” Research Data Repository, University of Bristol, UK. https://doi.org/10.5523/bris.2svuk8fzzqj5n2h5h26huho4sp (accessed 02/04/2019).

NUS (National Union of Students). (2014). Homes fit for study: The state of student housing in the UK. National Union of Students. Available at: https://www.nus.org.uk/Global/Homes\%20Fit\%20For\%20Stu dy/Housing\%20research\%20report_web.pdf (accessed 02/04/2019).

Oletic, D. \& Bilas, V. (2015). Design of sensor node for air quality crowdsensing. 2015 IEEE Sensors Applications Symposium (SAS), Zadar, 2015, pp. 1-5. https://doi.org/10.1109/SAS.2015.7133628

Plenario. (2019). About Plenario. http://plenar.io/about (accessed 02/04/2019).

Resch, B. Mittlboeck, M. Lipson, S. Welsh, M. Bers, J. Britter, R. Ratti, C. \& Blashcke, T. (2011). Integrated Urban Sensing: A Geo-sensor Network for Public Health Monitoring and Beyond. Massachusetts Institute of Technology. Paper 268, pp.1-21. Available at: http://hdl.handle.net/1721.1/64636 (accessed 02/04/2019).

Shilton, K. Burke, J. Estrin, D. Hansen, M. \& Srivastava, M. (2008). Participatory Privacy in Urban Sensing. MODUS 2008, St. Louis, MO. Available at: http://scholarworks.umass.edu/cgi/viewcontent.cgi?article=13 $58 \&$ context $=$ esence $($ accessed 02/04/2019).

Simões, N.A.V. \& de Souza, G.B. (2016). A low cost automated data acquisition system for urban sites temperature and humidity monitoring based in Internet of Things. 2016 First International Symposium on Instrumentation Systems,
Circuits and Transducers (INSCIT), Belo Horizonte, 2016, pp. 107-112. https://doi.org/10.1109/INSCIT.2016.7598189

Smart Citizen. (2019). Smart Citizen (v2 Beta): Open source technology for citizens political participation in smarter cities. https://smartcitizen.me/ (accessed 02/04/2019).

UK Power. (2019). Gas \& Electricity Tariff Prices per kWh. https://www.ukpower.co.uk/home_energy/tariffs-per-unitkwh (accessed 02/04/2019).

University of Bristol. (2019). Residences. http://www.bristol.ac.uk/accommodation/undergraduate/resid ences/ (accessed 02/04/2019).

USEPA (U.S. Environmental Protection Agency). (2013). Moisture Control Guidance for Building Design, Construction and Maintenance. Available at: https://www.epa.gov/sites/production/files/201408/documents/moisture-control.pdf (accessed 02/04/2019).

Webb, G. T., Vardanega, P. J. and Middleton, C. R. (2015). Categories of SHM Deployments: Technologies and Capabilities. Journal of Bridge Engineering (ASCE), 20(11): 04014118, http://dx.doi.org/10.1061/(ASCE)BE.19435592.0000735

WHO (World Health Organisation). (2009). Damp and Mould: health risks, prevention and remedial actions. [pdf] WHO Regional Office for Europe. Available at: http://www.euro.who.int/_data/assets/pdf_file/0003/78636/D amp_Mould_Brochure.pdf (accessed 02/04/2019).

Xively. (2019). Xively homepage. https://www.xively.com/ (accessed 02/04/2019).

Zeiger, F. \& Huber, M. (2014). Demonstration Abstract: Participatory sensing enabled environmental monitoring in smart cities. IPSN-14 Proceedings of the 13th International Symposium on Information Processing in Sensor Networks, Berlin, 2014, pp. 337-338. https://doi.org/10.1109/IPSN.2014.6846791 